\title{
Reassessment of the Phylogenetic Position of Caulobacter subvibrioides
}

\author{
L. I. SLY, ${ }^{1 *}$ MARIAN M. CAHILL,${ }^{1}$ K. MAJEED,${ }^{1} \dagger$ AND G. JONES ${ }^{2}$ \\ Australian Collection of Microorganisms, Centre for Bacterial Diversity and Identification, Department of Microbiology, \\ The University of Queensland, Brisbane, ${ }^{1}$ and CSIRO Division of Water Resources, Griffith, New South Wales, ${ }^{2}$ Australia
}

\begin{abstract}
Determination of the 16S rRNA gene sequence of Caulobacter subvibrioides ATCC $15264^{\mathrm{T}}(\mathrm{T}=$ type strain) confirmed that this species is a member of the alpha subclass of the Proteobacteria and showed that it is phylogenetically most closely related to the Caulobacter group comprising the species Caulobacter bacteroides, Caulobacter crescentus, and Brevundimonas (Pseudomonas) diminuta, for which 16S rRNA sequences of the type strains are currently available. The closest known relative of strain ATCC $15264^{\mathrm{T}}$ among these species is $B$. diminuta (level of direct pairwise sequence similarity, 95\%). On the basis of its previously determined 16S rRNA sequence (accession number M83797), $C$. subvibrioides is most closely related to Sphingomonas adhaesiva in the alpha-4 subgroup (level of similarity, 97.7\%). Analysis of the hydroxy fatty acids of $C$. subvibrioides ATCC $15264^{T}$ showed that the 2-hydroxymyristic acid which is characteristic of the genus Sphingomonas was absent.
\end{abstract}

In 1992 Stahl et al. (20) reported on the phylogeny of the genus Caulobacter. These authors noted that most of the caulobacters, which belong to the alpha subclass of the Proteobacteria $(20,23)$, made up a diverse but coherent phylogenetic assemblage based on a comparison of their 16S rRNA sequences; the only exception was Caulobacter subvibrioides, which was only peripherally related to the main Caulobacter assemblage. However, insufficient outgroup reference sequences were used for accurate phylogenetic positioning of $C$. subvibrioides, and the relationship of this organism with other members of the alpha subclass of the Proteobacteria remained unclear.

Later, Hugenholtz et al. (4) showed that the published $16 \mathrm{~S}$ rRNA sequence of $C$. subvibrioides CB81 (nucleotide sequence accession number M83797) was most closely related to the sequences of members of the alpha- 4 subgroup of the Proteobacteria and that C. subvibrioides grouped with Blastobacter natatorius (19), Erythrobacter longus (15), and Porphyrobacter neustonensis (3). Subsequently, it was found that the genera Sphingomonas and Rhizomonas were also members of the expanding alpha-4 subgroup $(21,22)$. Strain CB81 was designated the type strain of the species by Poindexter (12) and was deposited in the American Type Culture Collection as strain ATCC 15264. The culture used by Stahl et al. (20) also originated as strain CB81 but has had a different history since.

In our experience the designated type strain of $C$. subvibrioides, strain ATCC 15264 (17), is not a typical member of the alpha-4 subgroup and appears to be typical of the caulobacters. Consequently, we decided to examine the hydroxy fatty acid profile of the type strain of $C$. subvibrioides to see if it contained the signature 2-hydroxymyristic acid characteristic of the fatty acids of other members of the alpha-4 subgroup, including Sphingomonas spp. (24), Rhizomonas spp. (21, 22), and $B$. natatorius (16).

C. subvibrioides ATCC $15264^{\mathrm{T}}(\mathrm{T}=$ type strain) was received by us from the American Type Culture Collection in 1982 and was deposited in the Australian Collection of Micro-

* Corresponding author. Phone: 6173365 2396. Fax: 61733651566. E-mail: sly@biosci.uq.oz.au.

$\dagger$ Present address: School of Pharmaceutics and Pharmacy Practice, Victorian College of Pharmacy, Monash University, Melbourne, Australia. organisms as strain ACM $2483^{\mathrm{T}}$. Cells from our original freezedried ampoules were grown in peptone-yeast extract medium (18) with agitation in an environmental incubator at $28^{\circ} \mathrm{C}$, harvested by centrifugation, washed twice in distilled water, and freeze-dried. Hydroxy fatty acids were extracted and methylated by direct acid methanolysis $\left(2 \mathrm{ml}\right.$ of $2 \mathrm{M}$ methanolic $\mathrm{HCl}, 85^{\circ} \mathrm{C}$, $18 \mathrm{~h}$ ). Fatty acid esters (FAMES) were extracted three times in 1 $\mathrm{ml}$ of hexane-chloroform (4:1) after $1 \mathrm{ml}$ deionized water was added to the extract to improve phase separation. The combined extract $(3 \mathrm{ml})$ was dried under nitrogen, $50 \mu \mathrm{l}$ of chloroform was added, and the hydroxy acids were converted to their corresponding trimethylsilyl (TMS)-ether derivatives with bis(trimethylsilyl)trifluoroacetamide-1\% trimethylchlorosilane $(50 \mu \mathrm{l})$ during incubation for $2 \mathrm{~h}$ at $70^{\circ} \mathrm{C}(6)$. Following cooling to room temperature, the samples were evaporated to dryness with nitrogen gas and then redissolved in chloroform $(200 \mu \mathrm{l})$. TMS-hydroxy FAMES were analyzed by gas chromatographymass spectrometry by using a Varian model 3300 gas chromatograph linked directly to a Hewlett-Packard model 5970 mass selective detector. Samples $(1 \mu \mathrm{l})$ were injected in splitless (1-min) mode. The analytical column used was an Alltech BP5 column ( $25 \mathrm{~m}$ by $0.22 \mathrm{~mm}$ [inside diameter]; phase thickness, $0.33 \mu \mathrm{m})$, the oven temperature was programmed to increase at a rate of $4^{\circ} \mathrm{C} / \mathrm{min}$ from 150 to $270^{\circ} \mathrm{C}$ with 0 - and 7.5-min hold times, respectively, and the injection temperature was $260^{\circ} \mathrm{C}$. The helium carrier gas flow rate was $8 \mathrm{ml} / \mathrm{min}$. The mass spectrometer was run in total-ion chromatograph mode (50 to $500 \mathrm{amu}$ ). Constituent FAMEs were identified by comparing retention times and mass spectra with the retention times and mass spectra of TMS-derivatized fatty acid standards (4). The results of the analysis showed that no hydroxy fatty acids were present in C. subvibrioides ATCC $15264^{\mathrm{T}}$. As 2-hydroxymyristic acid was absent in $C$. subvibrioides but present in Blastobacter natatorius (16; this study), an organism with which the available $16 \mathrm{~S}$ rRNA sequence of $C$. subvibrioides (accession number M83797) shows $93.4 \%$ sequence similarity (4), the relationship between these two organisms was placed in doubt. We therefore decided to sequence the $16 \mathrm{~S}$ ribosomal DNA of C. subvibrioides ATCC $15264^{\mathrm{T}}$ in order to confirm or clarify the phylogenetic position of this organism.

Extraction of genomic DNA and amplification of the $16 \mathrm{~S}$ rRNA gene were performed as described by Dorsch and Stackebrandt (1). The PCR products were purified by using a Micro-Spin S-300 purification column (Pharmacia Biotech) as 


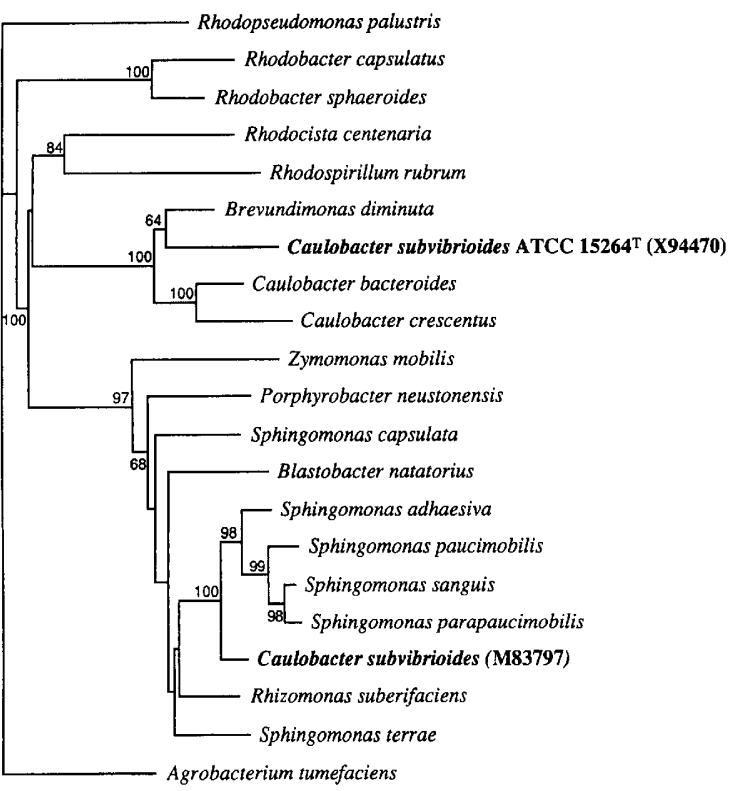

.10

FIG. 1. Unrooted phylogenetic tree obtained by a neighbor-joining analysis of $16 \mathrm{~S}$ rRNA sequences, showing the position of $C$. subvibrioides in the alpha subclass of the Proteobacteria. The scale bar represents 10 nucleotide substitutions per 100 nucleotides of 16S rRNA sequence. Bootstrap values from 100 analyses are shown at the branch points of the tree. The accession numbers of the sequences of the organisms used in the analysis are as follows: Blastobacter natatorius ACM 2507, X73043; Brevundimonas diminuta ATCC 11568, M59064 Caulobacter bacteroides ATCC 15254, M83796; Caulobacter crescentus CB2 (= ATCC 15252), X52281; Caulobacter subvibrioides ATCC 15264 ${ }^{\mathrm{T}}$, X94470; Cau lobacter subvibrioides CB81, M83797; Porphyrobacter neustonensis ACM 2844 L01785; Rhizomonas suberifaciens IFO 15211, D13737; Rhodobacter capsulatus ATCC 11166, D16428; Rhodobacter sphaeroides ATCC 17023, X53855; Rhodocista centenaria ATCC 43720, D12701; Rhodopseudomonas palustris ATCC 17001, L11664; Rhodospirillum rubrum ATCC 11170, M32020; Sphingomonas adhaesiva IFO 15099 (= GIFU 11458), D16146; Sphingomonas capsulata GIFU 11526 (= ATCC 14666), D16147; Sphingomonas parapaucimobilis IFO 15100 , D13724; Sphingomonas paucimobilis GIFU 2395 (= ATCC 29837), D16144; Sphingomonas sanguis ATCC 51382, D13726; Sphingomonas terrae IFO 15098, D13727; Zymomonas mobilis, Zym.mobili (Ribosomal RNA Database Project database). The sequence of Agrobacterium tumefaciens IAM 13129 (accession number D12784) was used as the outgroup.

described by the manufacturer. A PRISM Ready Reaction DyeDeoxy terminator cycle sequencing kit (Applied Biosystems, Foster City, Calif.) was used to directly sequence the PCR products by following the protocol provided by the manufacturer, and the reaction mixtures were sequenced automatically with an Applied Biosystems model 373A DNA sequencer. The $16 \mathrm{~S}$ ribosomal DNA sequences were aligned manually with representative bacterial $16 \mathrm{~S}$ rRNA sequences contained from the Ribosomal RNA Database Project database (8). Positions where length and sequence variations made alignment uncertain were omitted from the analysis, and the final analysis included 1,102 bases. Pairwise evolutionary similarities and distances (7) were computed by using the DNADIST program in the PHYLIP 3.4 software package (2). Phylogenetic trees were constructed by using the neighbor-joining method of Saitou and Nei (13). A bootstrap analysis with SEQBOOT PHYLIP 3.4 was performed to determine the statistical significance of branching patterns, and a consensus tree (data not shown) was produced by using CONSENSE (PHYLIP 3.4).

A comparison of the $C$. subvibrioides $16 \mathrm{~S}$ rRNA sequence obtained in this study with the sequences of a range of members of the alpha subclass of the Proteobacteria (Fig. 1) re- vealed that $C$. subvibrioides ATCC $15264^{\mathrm{T}}$ clustered with other members of the Caulobacter assemblage and was most closely related (level of similarity, 95\%) to Brevundimonas (Pseudomonas) diminuta (14), which Stahl et al. (20) have shown is a close phylogenetic relative of the caulobacters. The phylogenetic tree shown in Fig. 1 confirms that on the basis of its original sequence (accession number M83797) C. subvibrioides continues to cluster with members of the alpha-4 subgroup and not the caulobacters.

Morphologically, C. subvibrioides ATCC $15264^{\mathrm{T}}$ matches the description of the species $(11,12)$ and is unlike members of the alpha-4 subclass, all of which lack prosthecate appendages. When considered with the chemotaxonomic and phylogenetic data presented above, the evidence suggests that the original sequence that was determined (accession number M83797) is not the sequence of $C$. subvibrioides, but rather is the sequence of an organism that is most closely related to Sphingomonas adhaesiva (level of rRNA sequence similarity, 97.7\%). The phylogenetic analysis in which the new sequence of $C$. subvibrioides was used showed that the three Caulobacter species for which $16 \mathrm{~S}$ rRNA sequences of the type strains are available cluster together. This observation is supported by the findings of Nikitin et al. (10), who showed that C. subvibrioides ATCC $15264^{\mathrm{T}}$ is phylogenetically closely related to the other species of the genus Caulobacter on the basis of the fatty acid compositions of their cellular membranes. The current data also confirm the close relationship between Brevundimonas diminuta and the Caulobacter group observed by Stahl et al. (20). The genus Caulobacter currently contains 11 species $(9,17)$, and sequences for the remaining majority of species will have to be determined before any definite conclusions about the phylogenetic coherence of this group can be made, but the indications from this and previous research $(10,20)$ support the hypothesis that this is a coherent taxon.

Nucleotide sequence accession number. The nucleotide sequence determined in this study for $C$. subvibrioides ATCC $15264^{\mathrm{T}}\left(=\mathrm{ACM} 2483^{\mathrm{T}}\right)$ has been deposited in the EMBL Data Library, Cambridge, United Kingdom, under accession number X94470.

Part of this research was funded by an Australian Research Council grant to L.I.S., and this is gratefully acknowledged.

\section{REFERENCES}

1. Dorsch, M., and E. Stackebrandt. 1992. Some modifications in the procedure of direct sequencing of PCR amplified 16S rDNA. J. Microbiol. Methods 16:271-279.

2. Felsenstein, J. 1991. PHYLIP version 3.4. University of Washington, Seattle.

3. Fuerst, J. A., J. A. Hawkins, A. Holmes, L. I. Sly, C. J. Moore, and E. Stackebrandt. 1993. Porphyrobacter neustonensis gen. nov., sp. nov., an aerobic bacteriochlorophyll-synthesizing budding bacterium from freshwater. Int. J. Syst. Bacteriol. 43:125-134.

4. Hugenholtz, P., E. Stackebrandt, and J. A. Fuerst. 1994. A phylogenetic analysis of the genus Blastobacter with a view to its future reclassification. Syst. Appl. Microbiol. 17:51-57.

5. Jones, G. J., P. D. Nichols, R. B. Johns, and J. D. Smith. 1987. The effect of mercury and cadmium on the fatty acid and sterol composition of the marine diatom Asterionella glacialis. Phytochemistry 26:1343-1348.

6. Jones, G. J., P. D. Nichols, and P. M. Shaw. 1994. Analysis of sterols and hopanoids in bacteria and eukaryotic microorganisms, p. 163-195. In M. Goodfellow and A. G. O'Donnell (ed.), Chemical methods in prokaryote systematics. John Wiley and Sons, Chichester, United Kingdom.

7. Jukes, T. H., and C. R. Cantor. 1969. Evolution of protein molecules, p. 21-132. In H. N. Munro (ed.), Mammalian protein metabolism. Academic Press, New York, N.Y.

8. Maidak, B. L., N. Larsen, J. McCaughey, R. Overbeck, G. J. Olsen, K. Fogel, J. Blandy, and C. R. Woese. 1994. The Ribosomal Database Project. Nucleic Acids Res. 22:3483-3487.

9. Moore, W. E. C., and L. V. H. Moore. 1992. Index of the bacterial and yeast nomenclatural changes. American Society for Microbiology, Washington, D.C.

10. Nikitin, D. I., O. Y. Vishnewetskaya, K. M. Chumakov, and I. V. Zlatkin. 
1990. Evolutionary relationship of some stalked and budding bacteria (genera Caulobacter, "Hyphobacter," Hyphomonas and Hyphomicrobium) as studied by the new integral taxonomical method. Arch. Microbiol. 153:123-128.

11. Poindexter, J. 1989. Genus Caulobacter, p. 1924-1939. In J. T. Staley, M. P. Bryant, N. Pfennig, and J. G. Holt (ed.), Bergey's manual of systematic bacteriology, vol. 3. Williams \& Wilkins, Baltimore, Md.

12. Poindexter, J. S. 1964. Biological properties and classification of the Caulobacter group. Bacteriol. Rev. 28:231-295.

13. Saitou, N., and M. Nei. 1987. The neighbor-joining method: a new method for reconstructing phylogenetic trees. Mol. Biol. Evol. 4:406-425.

14. Segers, P., M. Vancanneyt, B. Pot, U. Torck, B. Hoste, D. Dewettinck, E. Falsen, K. Kersters, and P. De Vos. 1994. Classification of Pseudomonas diminuta Leifson and Hugh 1954 and Pseudomonas vesicularis Busing, Doll, and Freytag 1953 in Brevundimonas gen. nov. as Brevundimonas diminuta comb. nov. and Brevundimonas vesicularis comb. nov., respectively. Int. J. Syst. Bacteriol. 44:499-510.

15. Shiba, T., and U. Simidu. 1982. Erythrobacter longus gen. nov., sp. nov., an aerobic bacterium which contains bacteriochlorophyll $a$. Int. J. Syst. Bacteriol. 32:211-217.

16. Sittig, M., and P. Hirsch. 1992. Chemotaxonomic investigation of budding and/or hyphal bacteria. Syst. Appl. Microbiol. 15:209-222.

17. Skerman, V. B. D., V. McGowan, and P. H. A. Sneath. 1989. Approved lists of bacterial names, amended ed. American Society for Microbiology, Washington, D.C

18. Skerman, V. B. D., L. I. Sly, and M.-L. Williamson. 1983. Conglomeromonas largomobilis gen. nov., sp. nov., a sodium-sensitive, mixed-flagellated organism from fresh waters. Int. J. Syst. Bacteriol. 33:300-308.

19. Sly, L. I. 1985. Emendation of the genus Blastobacter Zavarzin 1961 and description of Blastobacter natatorius sp. nov. Int. J. Syst. Bacteriol. 35:40-45.

20. Stahl, D. A., R. Key, B. Flesher, and J. Smit. 1992. The phylogeny of marine and freshwater caulobacters reflects their habitat. J. Bacteriol. 174:21932198.

21. Takeuchi, M., H. Sawada, H. Oyaizu, and A. Yokota. 1994. Phylogenetic evidence for Sphingomonas and Rhizomonas as nonphotosynthetic members of the alpha-4 subclass of the Proteobacteria. Int. J. Syst. Bacteriol. 44:308314 .

22. van Bruggen, A. H. C., K. N. Jochimsen, E. M. Steinberger, P. Segers, and M. Gillis. 1993. Classification of Rhizomonas suberifaciens, an unnamed Rhizomonas species, and Sphingomonas spp. in rRNA superfamily IV. Int. J. Syst. Bacteriol. 43:1-7.

23. Woese, C. R., E. Stackebrandt, W. G. Weisburg, B. J. Paster, M. T. Madigan, V. J. Fowler, C. M. Hahn, P. Blanz, R. Gupta, K. H. Nealson, and G. E. Fox. 1984. The phylogeny of purple bacteria: the alpha subdivision. Syst. Appl. Microbiol. 5:315-326.

24. Yabuuchi, E., I. Yano, H. Oyaizu, Y. Hashimoto, T. Ezaki, and H. Yamamoto. 1990. Proposals of Sphingomonas paucimobilis gen. nov. and comb. nov., Sphingomonas parapaucimobilis sp. nov., Sphingomonas yanoikuyae sp. nov., Sphingomonas adhaesiva sp. nov., Sphingomonas capsulata comb. nov., and two genospecies of the genus Sphingomonas. Microbiol. Immunol. 34: 99-119. 